\title{
Comparing the COVID-19 Recession with the Great Depression
}

\author{
David C. Wheelock, Group Vice President and Deputy Director of Research
}

T he COVID-19-induced U.S. recession has been frequently compared with past recessions, including the Great Depression of the 1930s. Many commentators note that the economic contraction of 2020 is the deepest since 1947, when the Commerce Department's quarterly estimates of GDP begin, and possibly since the Great Depression. The Great Depression was likely the largest and longest slump in economic activity in U.S. history, though records for the eighteenth and nineteenth centuries are sketchy. Comparing the 2020 recession with the Great Depression is also fraught with measurement difficulties, but some rough comparisons based on various measures of economic activity are possible.

The Business Cycle Dating Committee of the National Bureau of Economic Research determined that on a quarterly basis economic activity peaked in the fourth quarter of 2019; though on a monthly basis, the peak occurred in February 2020 (https://www.nber.org/cycles/main.html). The Commerce Department estimates that inflation- adjusted (i.e., "real") gross domestic product (GDP) fell at annual rates of 5.0 percent in the first quarter of 2020 and 32.9 percent in the second quarter. Though severe, the contraction apparently was relatively brief; economic activity began to increase in May or June, and most forecasters currently expect that output will increase in the second half of 2020 unless the pandemic resurges to the point of necessitating widespread business closures.

Although official estimates of GDP begin in 1947, quarterly estimates of GNP (i.e., gross national product) are available for the Depression and earlier years. ${ }^{1}$ Figure 1 plots the real GNP series for the Depression alongside the path of real GDP from the fourth quarter of 2019 through the first two quarters of 2020. The data are set equal to 100 in the cycle peak quarters (the third quarter of 1929 and fourth quarter of 2019). The figure also plots forecasts for real GDP over the remainder of 2020 and $2021 .^{2}$ As the figure shows, the cumulative decline in economic activity during the first two quarters of the 2020 recession was

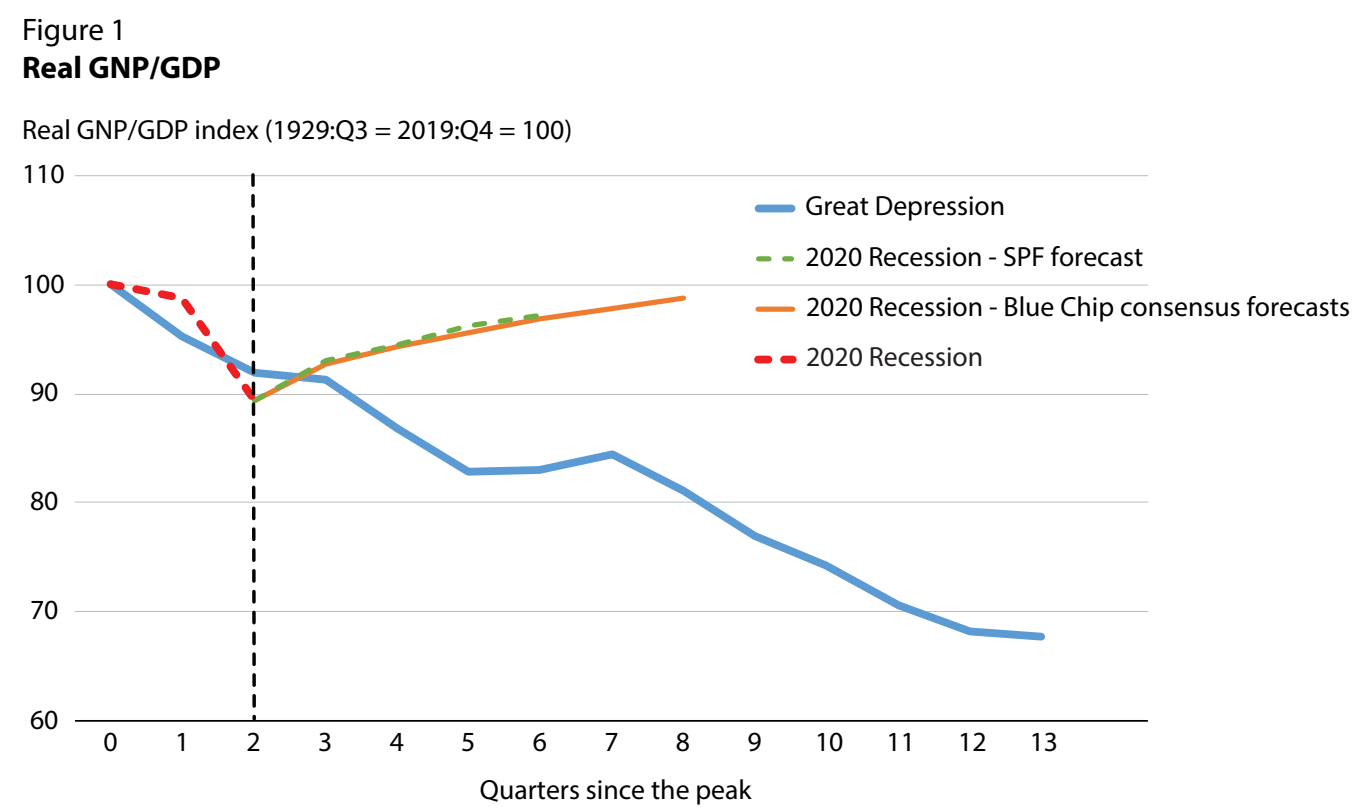

NOTE: SPF, Survey of Professional Forecasters. The dashed vertical line indicates the start of forecast data for the 2020 recession. SOURCE: Balke and Gordon (1986); FRED, Federal Reserve Bank of St. Louis; Haver Analytics ${ }^{\oplus}$; Federal Reserve Bank of Philadelphia; and author's calculations 
Figure 2

Industrial Production

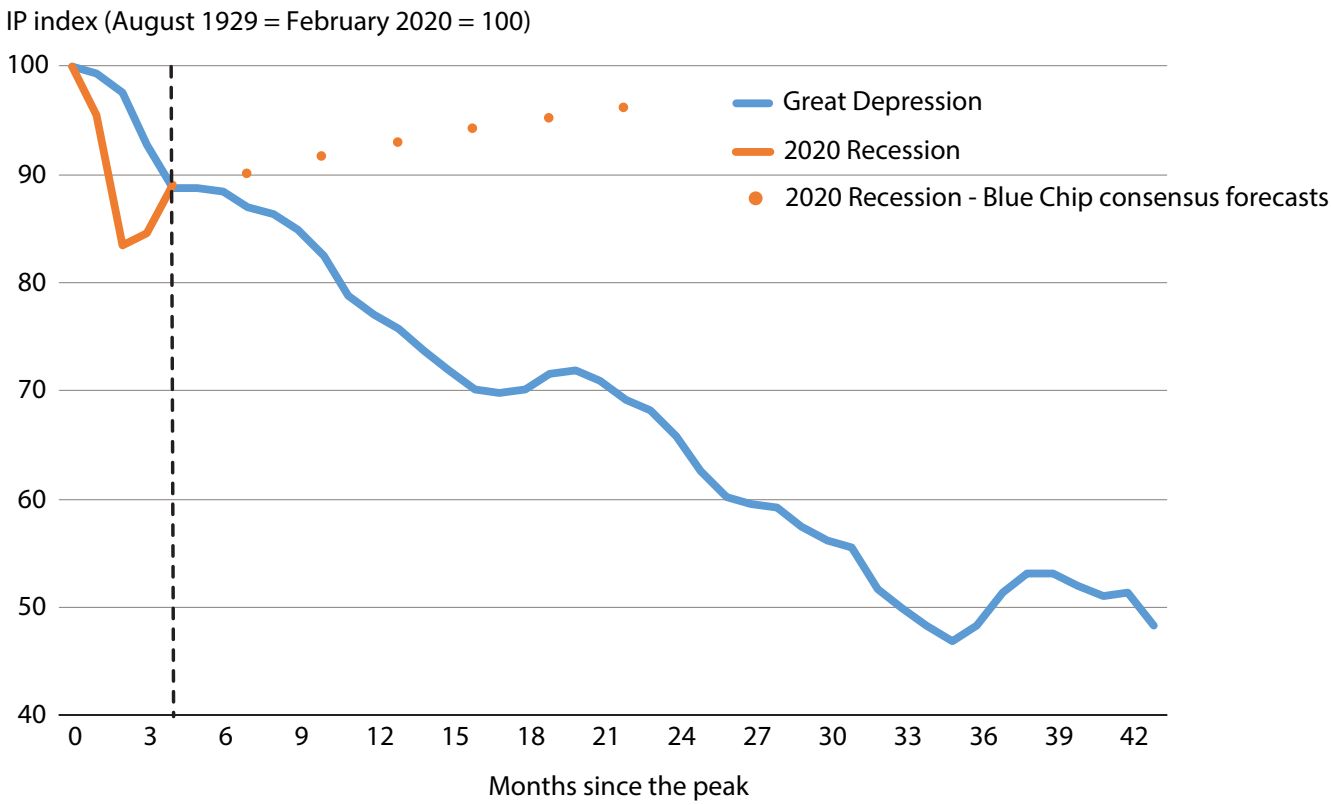

NOTE: The dashed vertical line indicates the start of forecast data for the 2020 recession. SOURCE: FRED ${ }^{\oplus}$, Federal Reserve Bank of St. Louis; Haver Analytics ${ }^{\oplus}$; and author's calculations.

Figure 3

\section{Unemployment Rate}

Unemployment rate $($ December $1929=$ February $2020=100)$

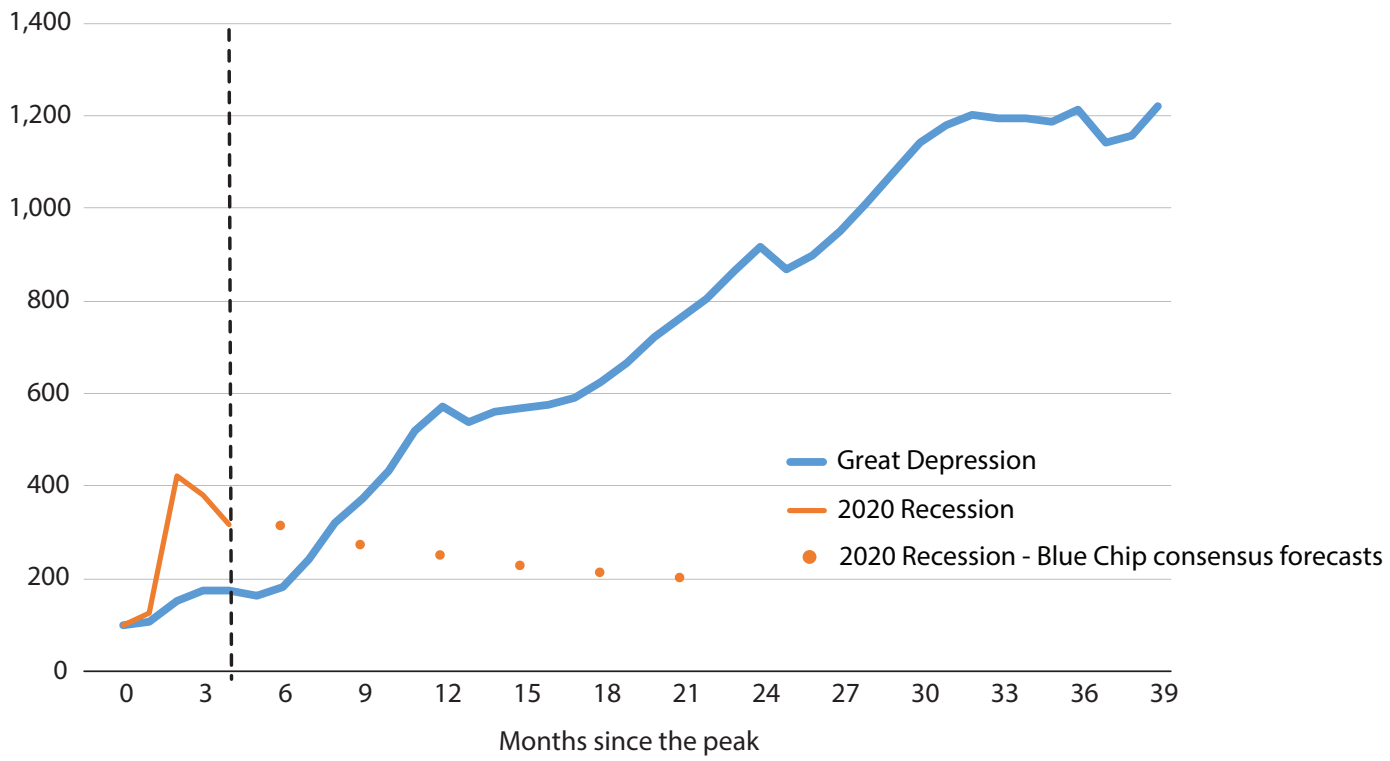

NOTE: The dashed vertical line indicates the start of forecast data for the 2020 recession.

SOURCE: FRED ${ }^{\circledR}$, Federal Reserve Bank of St. Louis; Haver Analytics ${ }^{\oplus}$; and author's calculations.

somewhat larger than the GNP decline during the first two quarters of the Great Depression. Moreover, the fall in real GDP during the second quarter of 2020 exceeded the largest one-quarter real GNP contraction during the
Depression. The Depression-era contraction continued for more than three years, however. At its low point in the first quarter of 1933, real GNP was just 68 percent of its 1929 peak. By contrast, consensus forecasts predict that 


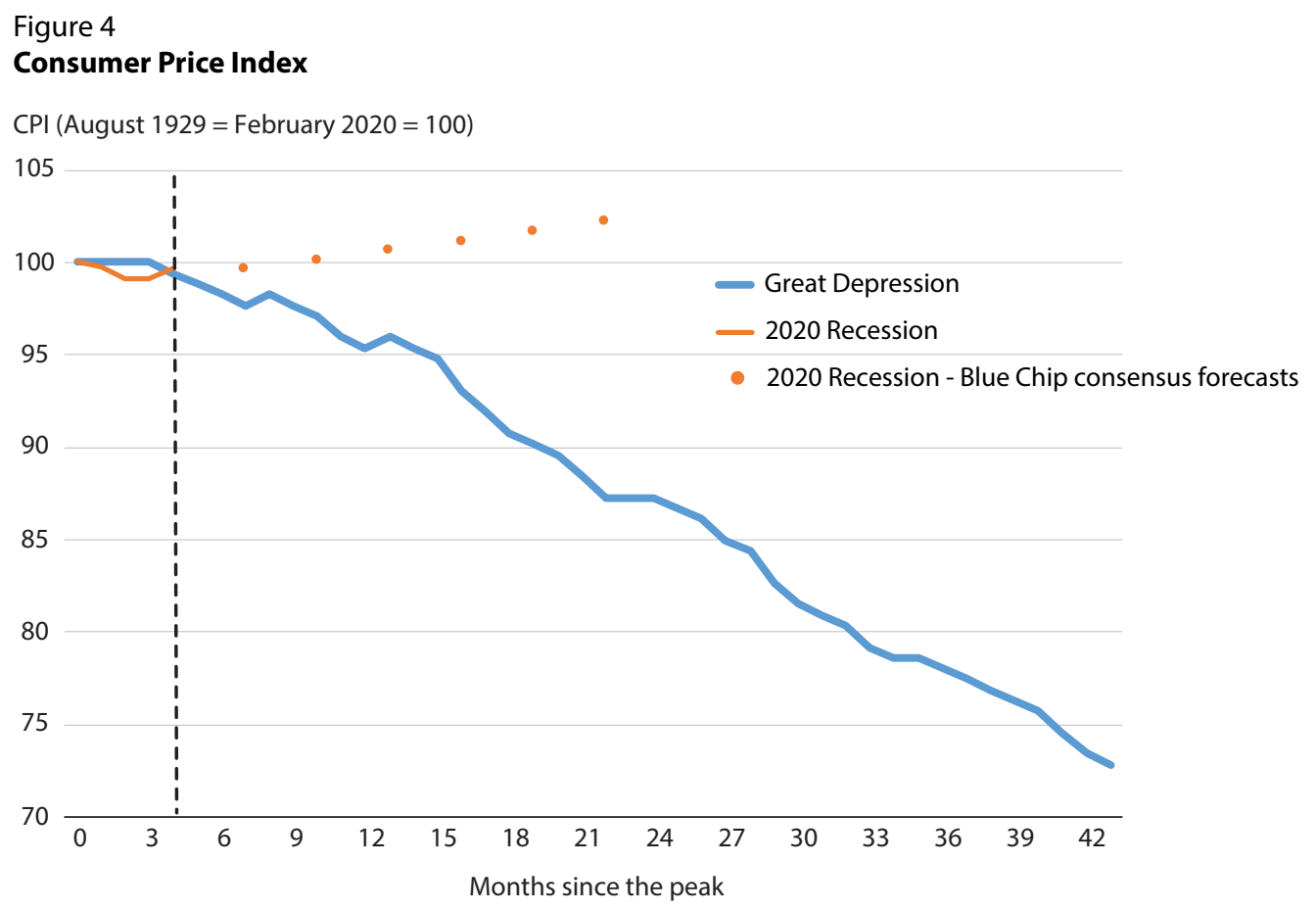

NOTE: The dashed vertical line indicates the start of forecast data for the 2020 recession. SOURCE: FRED ${ }^{\oplus}$, Federal Reserve Bank of St. Louis; Haver Analytics ${ }^{\oplus}$; and author's calculations.

the U.S. economy will expand in the second half of 2020 and into 2021 but that output will remain below the 2019 peak for at least several quarters.

A more consistently measured, but narrower, indicator of economic activity is the Index of Industrial Production (IP). ${ }^{3}$ The index fell sharply during the first two months of the 2020 recession, as shown in Figure 2, but then began to rise. In April the index was just 83 percent of its February level, but by June it was 89 percent of its February level. The February-to-April decline in IP was the largest twomonth decline in the history of the index, which begins in 1919. The cumulative declines in IP during the first four months of the Depression and the 2020 recession were similar. Although IP continued to fall for several quarters during the Depression, forecasters currently expect that IP will rise in coming months. (The orange dots on Figure 2 indicate Blue Chip consensus forecasts. ${ }^{4}$ )

The unemployment rate increased sharply in the 2020 recession, from 3.5 percent in February to nearly 15 percent in April before falling back to 11.1 percent in June. Figure 3 compares the unemployment rate in the 2020 recession and Great Depression. ${ }^{5}$ In contrast with the sharp rise at the beginning of the 2020 recession, the unemployment rate rose gradually during the initial months of the Great Depression, from about 2 percent in late 1929 to a bit less than 4 percent in June 1930.6 The unemployment rate continued to rise, however, reaching 25 percent in 1933, and remained above 10 percent throughout the 1930 s. $^{7}$ The Blue Chip consensus forecasts project a decline in the unemployment rate to below 10 percent by the end of 2020 and continued declines in 2021.

The 2020 contraction looks to be deep but short.

In addition to large declines in economic activity and employment, the price level also fell considerably during the Great Depression, as shown in Figure 4. At the business cycle trough in March 1933, the consumer price index (CPI) was 27 percent below its August 1929 level. Although the CPI fell during the first two months of the 2020 recession, it has since recovered to near its pre-recession level and is forecast to gradually rise.

Finally, Figure 5 plots the S\&P 500 (Standard and Poor's stock price index). Stock prices peaked in early October 1929 then famously crashed, plunging some 30 percent over the first three months of the Great Depression. By 1932, stock prices were down nearly 85 percent from their August 1929 level. Stock prices also fell sharply in the early days of the 2020 recession. From February to March, the S\&P 500 fell some 20 percent. However, by June, it had rebounded to 94 percent of its February level. 


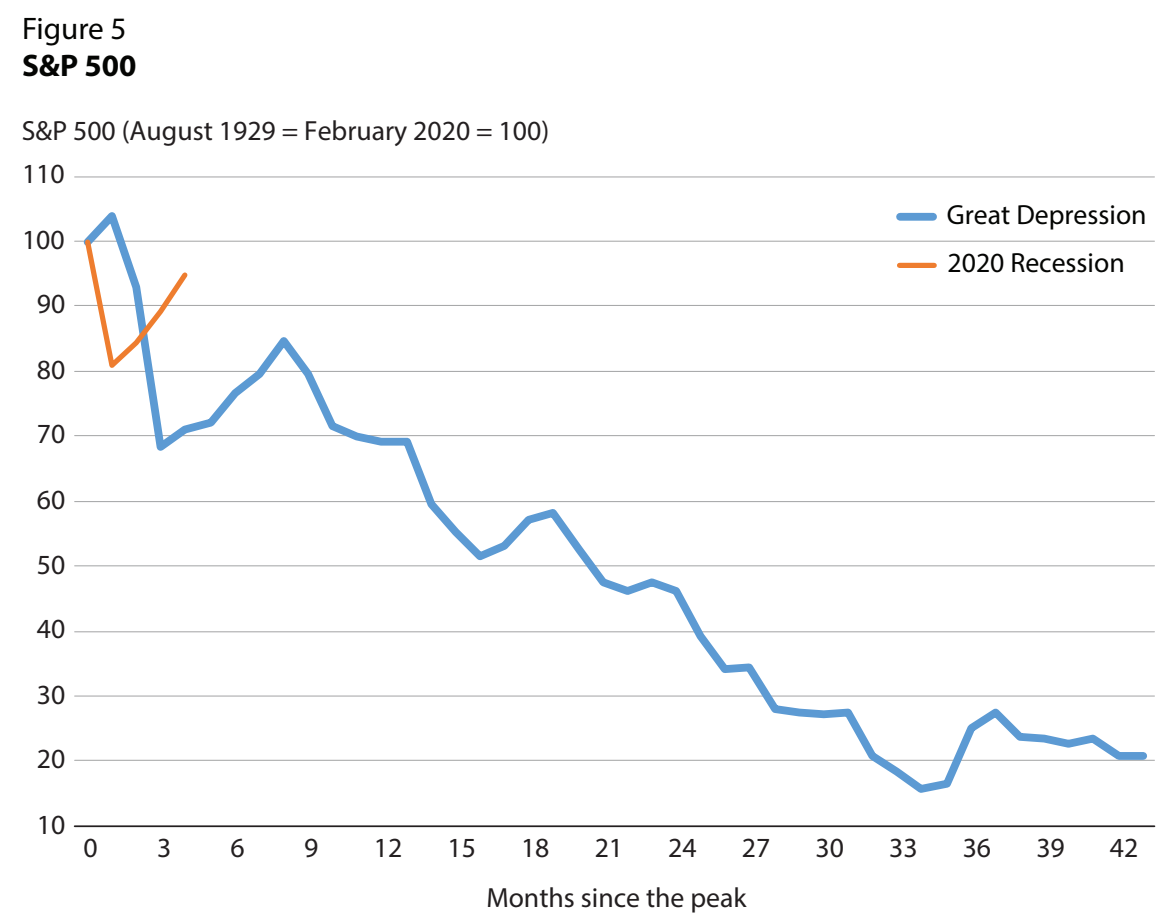

SOURCE: Haver Analytics ${ }^{\circledR}$ and author's calculations.

By almost any measure, the 2020 recession began with sharp declines in economic activity, employment, and equity prices that rivaled or exceeded the initial declines of the Great Depression. The Great Depression persisted, however, and when it finally reached a trough nearly four years later, economic activity, employment, and consumer and equity prices were all far below their initial levels. The 2020 contraction might turn out to be the sharpest, but also the shortest, in modern times and perhaps of all time in the United States. The debate among forecasters has recently focused on the likely pace of the recovery and whether the increase in economic activity since May will be sustained or turn out to be merely an uptick before a second dip. The virus and the public's response to it will likely make that determination.

\section{Notes}

1 GNP is a measure of the total finished goods and services produced by U.S. producers, regardless where production takes place, whereas GDP captures total production within the United States and its territories, regardless of the nationality of the producers. The GNP estimates used here are from Balke and Gordon (1986).
2 Figure 1 plots the Blue Chip consensus forecasts for 2020:Q2-2021:Q4 (as of July 10) and the Survey of Professional Forecasters forecast for 2020:Q2-202:Q2 (as of May 15, 2020).

${ }^{3}$ Data are from FRED ${ }^{\oplus}$, Federal Reserve Bank of St. Louis (https://fred.stlouisfed.org/series/INDPRO).

${ }^{4}$ Figure 2 assigns quarterly forecasts to the third month of each quarter.

5 The unemployment rate for the 2020 recession is the Bureau of Labor Statistics U-3 measure (https://fred.stlouisfed.org/series/UNRATE). The rate for the Great Depression was produced by G. H. Moore for the National Industrial Conference Board (https://fred.stlouisfed.org/series/ M0892AUSM156SNBR).

${ }^{6}$ The monthly unemployment rate series for the Depression begins in April 1929 and is quite volatile during 1929. Consequently, we use the value in December 1929 (set equal to 100) as the starting point, rather than the value at the business cycle peak in August 1929.

7 However, if persons employed in government relief jobs are included, the rate fell below 10 percent in 1936. See Margo (1993) for a discussion of unemployment rate measures and other labor market indicators for the Depression.

\section{References}

Balke, Nathan and Gordon, Robert J. "Data Appendix," in Robert J. Gordon, ed., The American Business Cycle, Continuity and Change. Chicago: University of Chicago Press, 1986, pp. 781-850.

Margo, Robert A. "Employment and Unemployment in the 1930s." Journal of Economic Perspectives, Spring 1993, 7(2), pp. 41-59. 